\title{
6. MORPHOLOGY AND STRUCTURAL TRENDS OF THE BARBADOS RIDGE COMPLEX IN THE VICINITY OF DEEP SEA DRILLING PROJECT SITES 541, 542, AND 543 AS REVEALED BY GLORIA LONG-RANGE SIDE-SCAN SONAR ${ }^{1}$
}

\author{
R. H. Belderson, N. H. Kenyon, and A. H. Stride, Institute of Oceanographic Sciences, Wormley, \\ Godalming, Surrey ${ }^{2}$
}

\begin{abstract}
An unusually fine-scale tectonic grain (with a $0.5-1-\mathrm{km}$ separation compared with several kilometers separation to north and south) has been found to lie parallel to the deformation front of the Barbados Ridge complex in the vicinity of Deep Sea Drilling Project Sites 541, 542, and 543. It is interpreted in terms of folds and faults. The high intensity of deformation along this part of the frontal zone is attributed to its being pressed up against the flanks of the Tiburon Rise, an oceanic basement ridge.

The only large gravity slide found is located on the steepest segment of the frontal zone of the deformed sediments.
\end{abstract}

\section{INTRODUCTION}

Between the Antilles volcanic arc (and adjacent Tobago Trough) and the deep floor of the Atlantic Ocean there is a broad band of relatively shallower seafloor. Published echo sounder and reflection profiler records over this ground revealed zones of complex deformation described as discontinuously reflective (see introductory chapter and site reports, this volume), where structure was "difficult to resolve" (Case and Holcombe, 1980).

Determination of the actual trends of the relief in plan view over a large proportion of this region was made with long-range side-scan sonar (GLORIA) (Stride et al., 1982), which examined swathes of seafloor up to $60 \mathrm{~km}$ wide. The varied directions of the ship's tracks should ensure that most of the morphological trends were detected.

The work was carried out during March and April, 1980 , on the Discovery, Cruise 109. Depth measurements were made with a precision depth recorder (PDR), while truer profiles of the relief were obtained by means of a narrow beam $\left(4^{\circ} \times 7^{\circ}\right)$ echo sounder. The ship's position was determined by means of a satellite navigation system in conjunction with dead reckoning (DR) between fixes that used a two-component electromagnetic log.

This chapter is only concerned with the small part of the total survey that covered the vicinity of DSDP Sites 541,542 , and 543 (Fig. 1). The preliminary results from this region were made available to the JOIDES Planning Committee before the holes were drilled. Provided here is a further review of the GLORIA data that should help in understanding the data from the three sites and the associated site surveys.

\footnotetext{
${ }^{1}$ Biju-Duval, B., Moore, J. C., et al., Init. Repts DSDP, 78A: Washington (U.S. Govt. Printing Office).

2 Address: Institute of Oceanographic Sciences, Wormley, Godalming, Surrey, United Kingdom
}

\section{MORPHOLOGY}

\section{Deformation Front}

The sonographs show that there is an abrupt but continuous boundary between the relatively smooth deep ocean floor and the band of deformed sediments that make up the shallower floor adjacent to the Antilles volcanic arc. The location and sinuosity of this boundary is shown in Figure 1, and an example of the sonographs on which it is based is shown in Figure 2. The deformation front passes west and south of the highest part of the Tiburon Rise, climbing about $900 \mathrm{~m}$ to pass over its lower flanks.

\section{Folds and Faults}

Immediately within the deformation front there is an approximately $10-\mathrm{km}$-wide zone of well-defined ridges with wavelengths of about 0.5 to $1 \mathrm{~km}$. Those ridges nearest to the deformation front, at about $16^{\circ} 10^{\prime} \mathrm{N}$, tend to be asymmetrical in cross-section, with gentle west-facing slopes and steeper east-facing slopes. They have a height of about $10 \mathrm{~m}$. Individual ridges within the zone as a whole can be followed for up to about 12 $\mathrm{km}$. They are only slightly sinuous and largely parallel, but there are also some signs of division and cross-cutting (Fig. 2), which we attribute to folding and faulting.

North and south of the ground shown in Figure 1 the frontal zone of the deformed sediments has a coarsergrained relief, with ridges that are typically spaced about $3.5 \mathrm{~km}$.

\section{Gravity Slide}

South of the Tiburon Rise the overlapping sonographs provide clear signs of a substantial debris flow (Fig. 1), which appears as a sharply defined "bright" patch, presumably due to the presence of a fine-scale roughness whose elements cannot be resolved (Fig. 3). The path followed by the debris flow (its "chute") is located on the northward facing slope of the frontal zone and widens downslope. At the deformation front there 


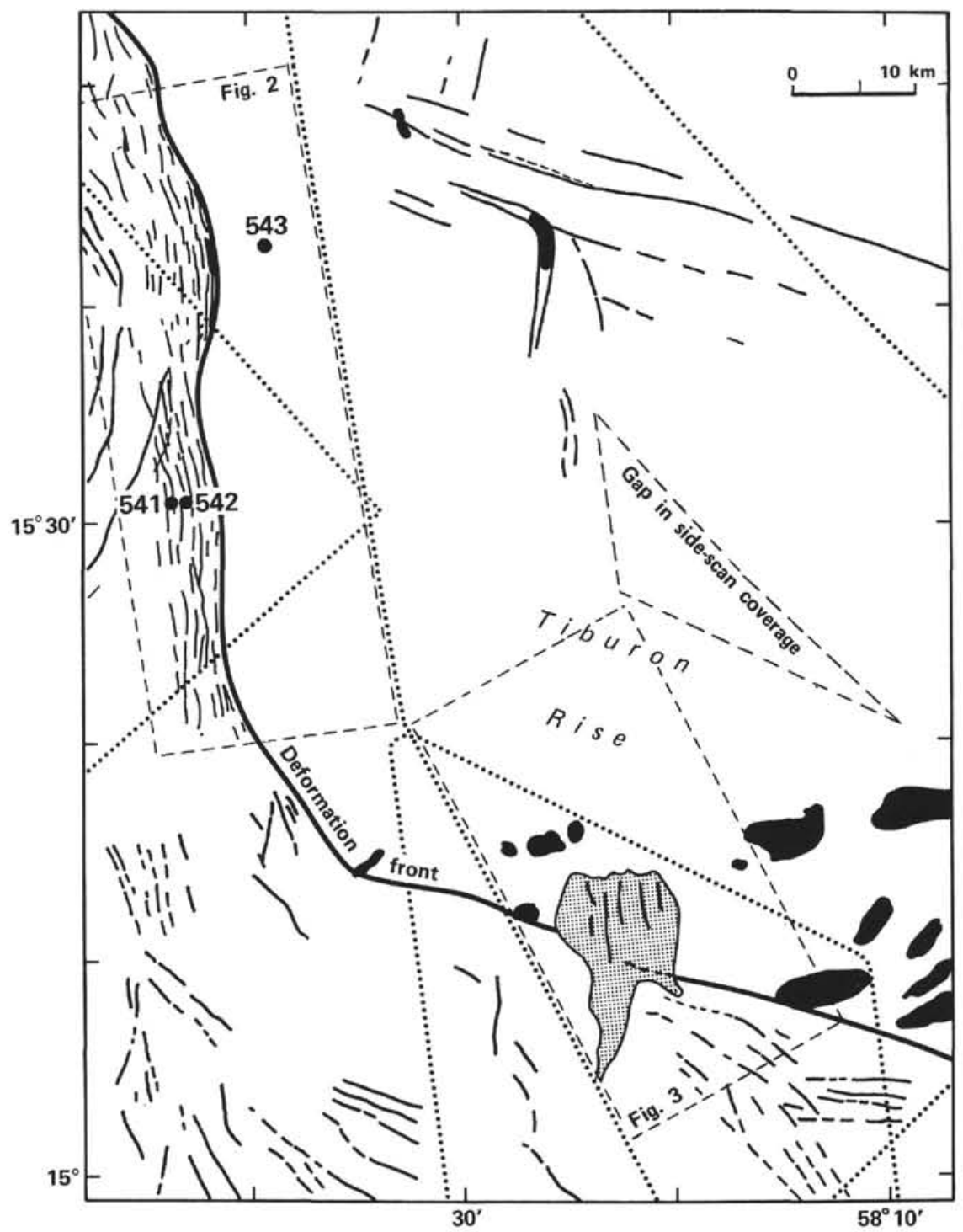

Figure 1. Somewhat schematized bed morphology in the vicinity of DSDP Sites 541 to 543 , as revealed by almost total cover with GLORIA long-range side-scan sonar, with views from several directions. (The structural grain of the Barbados Ridge complex [left and bottom] is largely parallel with the deformation front. The oceanward floor [top and right] is largely smooth except for some low ridges indicating trends of the oceanic basement and some basement outcrops seen as rough floor [black]. The debris flow is stippled, and the ship's courses are dotted. The limits of Figs. 2 and 3 are shown by dashed lines.)

is an abrupt lateral increase in width of the rough ground where the chute gives way to the depositional lobe, occupying an area of about $100 \mathrm{~km}^{2}$. Thus the debris spreads out laterally along the deepest floor, as well as northward up the gentle slope of the Tiburon Rise, probably to a level some tens of meters above the base of the slope. This slide was the only one detected. It may be significant, therefore, that it is located on the steepest segment $\left(4.5^{\circ}\right)$ of the frontal zone.

\section{DISCUSSION}

The sonographs on which Figure 1 is based show conclusively that the surface of the deformed sediment has a relatively simple pattern of ridges and troughs, most of which lie more or less parallel with the deformation front. The new data therefore dispose of the possibility that the terrain, however discontinuously reflective, is chaotic. Indeed, the ridges and troughs are likely to indicate the strike of the folds and the trace of the faults such as were recognized in DSDP cores of Sites 541 and 542 and in the reflection profiles (BijuDuval et al., 1981). We tentatively conclude that the relative steepness of the eastern limbs of the folds is accentuated by the reverse faults or thrusts that mostly extend along the strike of the folds. If we assume that the reverse fault or thrust recognized at Site 541 at a depth of $280 \mathrm{~m}$ reaches the surface at a ridge $0.5 \mathrm{~km}$ to the east, it will then have an average dip greater than about $25^{\circ}$. 


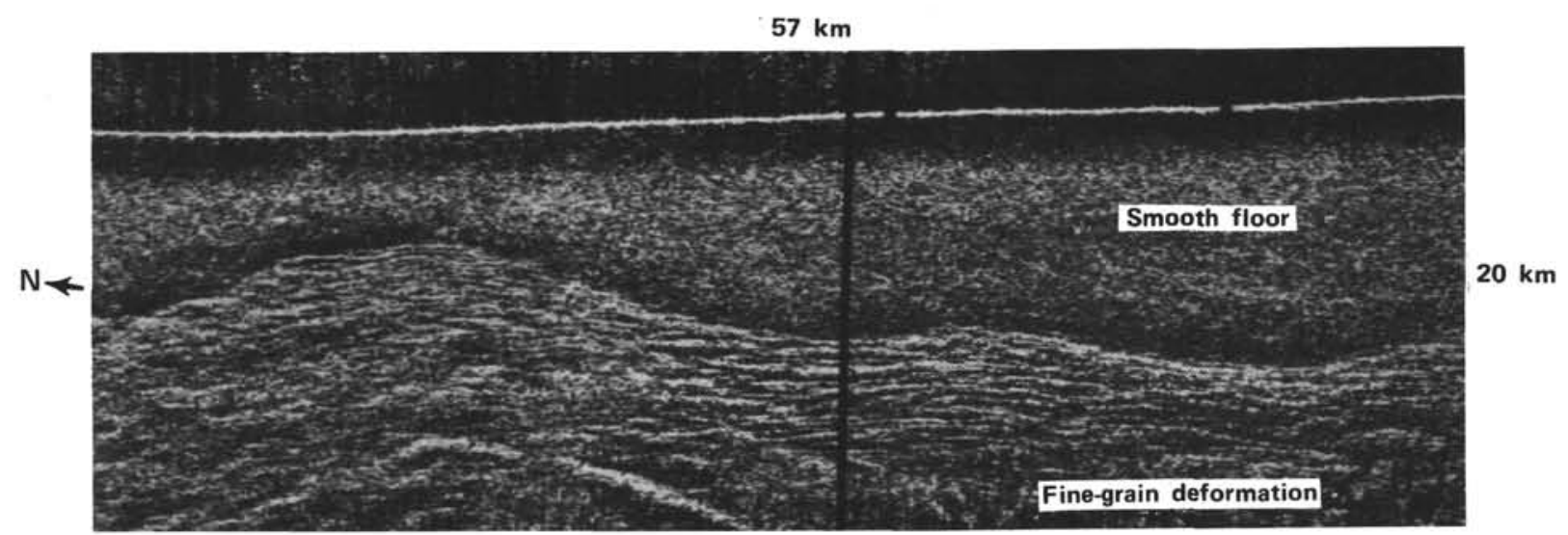

Figure 2. Sonograph covering the area that includes DSDP Sites 541, 542, and 543 and showing the deformation front and fine-scale structural grain of the outermost zone of the Barbados Ridge complex and the smooth floor beyond. (For location see Fig. 1.)

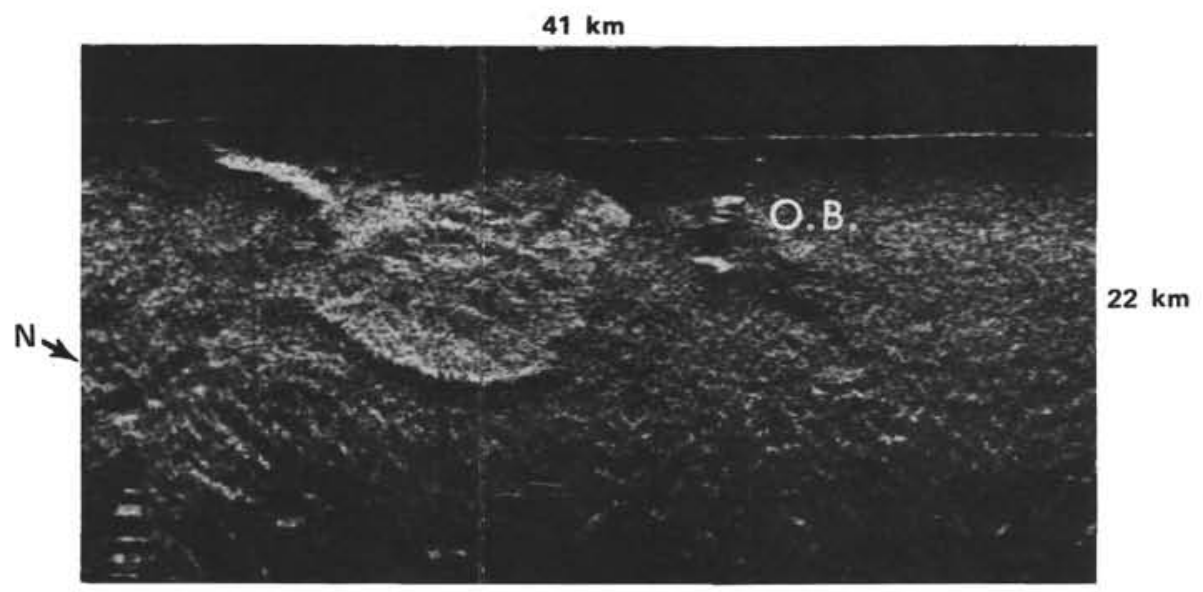

Figure 3. Sonograph showing the debris flow (light tone) and part of the chute down which it travelled. (Further detail of the debris-flow chute and depositional lobe and the deformation front in its vicinity were seen on other sonographs. Small outcrops of oceanic basement on the Tiburon Rise are labelled O.B. A zig-zag pattern due to refraction is present across the lower third of the sonograph. For location see Fig. 1.)

The frontal zone of the deformed sediments shown in Figure 1 is not typical of the Barbados Ridge complex as a whole for three reasons. First, it shows that fine-scale structural grain is present in a $10-\mathrm{km}$-wide zone in the vicinity of the deformation front, whereas further north and south only larger-scale folding is observed near the front (Stride et al., 1982). Second, the deformation front in Figure 1 is mostly steeper than to the north or south. And third, the steepest part of that front is associated with a large debris flow. We conclude that these local differences result from the compression of this part of the Barbados Ridge complex against the flanks of the upstanding ridge of oceanic basement known as the Tiburon Rise. The resulting deformation is thus more intense than elsewhere. Therefore DSDP Sites 541 and 542 were located on ground that cannot be considered as typical of much of the outer part of the Barbados Ridge complex.

\section{REFERENCES}

Anonymous, 1981. Cruise summaries, Leg 78A, eastern Caribbean Sea. JOIDES J., 7:10-21.

Biju-Duval, B., Moore, J. C., Blackington, G., Bergen, J. A., Claypool, G. E., Cowan, D. S., Guerra, R. T., Hemleben, C. H. J., Marlow, M. S., Natland, J. H., Pudsey, C. J., Renz, G. W., Tardy, M., Willis, M. E., Wilson, D., and Wright, A. A., 1981. Premiers résultats des forgage IPOD implantés lors de la croisiére 78A du Glomar Challenger au nord-est de la ride de la Barbade (arc des Petites Antilles): tectonique frontale d'un prisme d'accrétion. C.R. Acad. Sci., Paris, 293:521-628.

Case, J. E., and Holcombe, T. L., 1980. Geologic tectonic map of the Caribbean region. U.S. Geol. Surv. Misc. Investigation Ser. Map I1100.

Stride, A. H., Belderson, R. H., and Kenyon, N. H., 1982. Structural grain, mud volcanoes and other features on the Barbados Ridge complex revealed by GLORIA long-range side-scan sonar. Mar. Geol., 49:187-196.

Date of Initial Receipt: July 13, 1982

Date of Acceptance: January 8, 1983 